\title{
REPRODUCTIVE PATTERN OF SOME MEGACHIROPTERAN BATS IN GHANA
}

\author{
S. YеBOAH \\ School of Biological Sciences, University of Cape Coast, Cape Coast, Ghana
}

\begin{abstract}
Surveys of megachiropteran bats (fruit bats) were carried out in two forest reserves and some areas outside the reserves in the Eastern Region of Ghana. The studies were undertaken during three seasons of the year: end of the major rainy season (July/August), end of the minor rainy season (November/ December), and end of the major dry season (March/ April). Ten of Ghana's 13 species of fruit bats were recorded in the area; the commonest species was Epomops franqueti. The highest number of bats was caught towards the end of the major dry season, mainly due to the abundance of nutritious seeds of Cedrella odorata in the area during this time of the year, and also due to new recruitments into the population. The population was lowest at the end of the major rainy season. The larger fruit bats (Epomophorus gambianus, Epomops franqueti, Myonicteris leptodon and Rousettus aegyptiacus) have two breeding seasons: the major one in July/ August and a minor one in March /April. With the smaller sized bats (Micropteropus pussilus and Scotonycteris zenkeri) there are also two breeding seasons but the major one occurs in November/ December and the minor one in April. The Ghanaian megachiropteran bats are capable of producing two litters in a year.
\end{abstract}

\section{Résumé}

Yевонн, S.: Habitude reproductrice de quelques chauve-souris mégacheiroptérans au Ghana. Les enquêtes sur les chauve-souris mégacheiroptérans (la roussette) étaient entreprises dans deux réserves naturelles et quelques zones hors de réserves dans Eastern Region du Ghana. Les études étaient entreprises pendant trois saisons de l'année: fin de la saison des pluies majeure (juillet/août), fin de la saison des pluies mineure (novembre/decembre), et fin de la saison sèche majeure (mars/avril). Dix sur les 13 espèces des roussettes du Ghana étaient enregistrées dans la zone; l'espèce la plus commune était Epomops franqueti. La plus grande quantité de chauve-souris étaient prises vers la fin de la saison sèche majeure surtout à cause de l' abondance de pépins nourrissants de Cedrella odorata dans la zone pendant cette époque de l' année et aussi à cause de nouveaux recrutments dans la population. La population était la plus faible à la fin de la saison des pluies majeure. Les roussettes (Epomophorus gambianus, Epomops franqueti, Myonicteris leptodon et Rousettus aegyptiacus) plus grandes ont deux saisons des amours: la majeure en juillet/août et une mineure en mars/avril. Avec les roussettes (Micropteropus pussilus et Scotonycteris zenkeri) plus petites, il y a également deux saisons des amours mais la majeure se produit en novembre/ decembre et la mineure en avril. Ainsi les chauvesouris mégacheiroptérans ghanéennes sont capables de produire deux portées dans une année.

\section{Introduction}

The megachiropteran bats (or fruit bats) are a group of bats that rely on nectar, pollen grains and fruits of plants for food and are, therefore, important in plant pollination and seed dispersal. The family Pteropidae, to which the fruit bats belong, has 11 genera in West Africa, all of which are represented in Ghana (Rosevear, 1965).

Studies on fruit bats in Ghana are scanty. The few studies have concentrated on distribution
(Booth, 1956, 1959; Jeffrey, 1974; Decher, 1996), ecology (Marshall \& McWilliams, 1962), bat-plant interactions (Ayensu, 1974; Baker \& Harris, 1957, 1959; Lack, 1978) and relative abundance (Yeboah, $1996,1998,2001)$. So far there is no documented information on reproduction and population dynamics. The present study, which looks at the reproductive and population patterns of some fruit bats in eastern Ghana is, therefore, aimed at forming the basis for further studies in these areas 
of research of the Ghanaian fruit bats in other parts of the country.

\section{Experimental}

Survey methodology

The study took place in the Abirem District of the Eastern Region, Ghana. Eight study sites were selected in the area for the survey (Fig. 1). Three of the sites were located in the Ajenjua Bepo Forest Reserve, two in the Mamang Forest Reserve and three outside the forest reserves. Three surveys were undertaken during three seasons: July/ August 2003, corresponding with the end of the first or major rainy season; November/December 2003 , corresponding with the end of the second or minor rainy season; March/April 2004, towards the end of the major dry season.

Bat surveys were conducted during two nights in each study site using three $12-\mathrm{m}$ mist nets. The three nets were hung on three different lengths of poles ( $5 \mathrm{~m}, 4 \mathrm{~m}$ and $3 \mathrm{~m}$ ) to catch bats at different levels of flight. Nets were erected across trails, adjacent to streams, and edges of forests, within the study site, because these were areas where nets could be erected without obstructions. The nets were opened in the evening (1800-1830 h UT) and collapsed early in the morning (0630-0730 $\mathrm{h}$ UT) after inspection. Captured bats were carefully removed from the nets, identified, forearm length measured, sexed, reproductive condition noted, weighed, and released. Bats caught for the first time were marked with a small amount of white cellulose paint on the inside of the wing patagum before release to avoid multiple counting.

\section{Results}

For uniformity and need for standardization all the numbers of bats caught in each study site were converted to numbers per mist net night, which is defined as the number caught per $100 \mathrm{~m}$



Fig. 1. Map of the study area showing the eight study sites 
mist net per night and is estimated as follows:

Total number caught $\times 100$

Number of nights $\times$ Total net length per site

A total of 990 megachiropteran bats were caught during the three surveys. With the exception of Megaloglossus woermann and Lissonycteris angolensis that were caught only in the Ajenjua Forest Reserve and Hypsignathus monstrosus that was caught only in the Mamang Forest Reserve, all the bat species are common to the two forest reserves. In Surveys I, II and III, 181, 232 and 577 megachiropteran bats, respectively, belonging to 10 species were caught (Table 1). The species are Hypsignathus monstrossus, Lissonycteris angolensis angolensis, Megaloglossus woermanni, Epomophorus gambianus, Epomops franqueti, Scotonycteris zenkeri, Myonycteris leptodon, Rousettus aegyptiacus occidentalis, Nannonycteris veldkampi and Microteropus pusillus.

The total number of bats caught in Survey III was the highest and is $218.8 \%$ higher than the number caught in Survey I (July/August) and $148.7 \%$ higher than that of Survey II (November/ December). With the exception of sites 4 and 5, the number of bats caught in each of the sites in Survey III (March/April) was higher than the combined numbers caught in the same sites during the two other surveys (Table 1). Also, with the exception of $E$. franqueti and $S$. zenkeri, all species of bats caught showed dramatic increases in numbers over the other two previous surveys (Table 1). H. monstrosus, L. angolensis angolensis and $M$. woermanni were caught for the first time during Survey III. H. monstrosus was caught in site 6 only (Table 1$)$.

The commonest bats in the study area were $E$. franqueti and E. gambianus of which 244 and 190 , respectively, were caught at an average catch rate (relative abundance) of $112.7 / \mathrm{mnn}$ and $88 /$ mnn, respectively. The highest number of bats, 188 individuals from 5 species, was caught in site 8 (part of the Mamang Forest Reserve adjacent to the Auro Forest Reserve) at an average catch rate of $87.1 / \mathrm{mnn}$. This was followed by site 3 (part of the Ajenjua Forest Reserve with Cedrella plantation) where 173 individual bats from two species were caught at an average catch rate of $80.1 / \mathrm{mnn}$ (Table 1).

Most of the female bats caught in Survey I were either gravid (pregnant) or lactating with the young attached to the nipple. All (100\%) the $E$. franqueti females caught were either pregnant or lactating (Table 2). Eighty-one per cent of the $E$. gambianus females caught were pregnant or lactating while the corresponding figures for $M$. leptodon and $R$. aegyptiacus are 73 and 35 per cent, respectively (Table2). In Survey II only two species were pregnant and these were $M$. pusillus (100\% pregnancy) and S. zenkeri (35\%) (Table 2). In the Survey III, however, five species were found pregnant, albeit with low percentages. These were E. gambianus (44.1\%), E. franqueti (10\%), M. leptodon (48.6\%), R. aegyptiacus (11.1\%) and $M$. pussilus (30\%).

\section{Discussion}

Ten of Ghana's 13 species of megachiropteran bats were recorded in the study area during the surveys. For the Ajenjua Forest Reserve the relative abundance of $135.2 / \mathrm{mnn}$ recorded in Survey III (March/April) was by far higher than those of the two previous surveys. The large number of bats caught in Survey III for all species of bats was probably due to food abundance. During the time of the study the soft nutritious seeds of the Cedrella were in abundance on the trees as a source of food for the bats including the young reproduced during the previous breeding season. It is, however, worth noting that this peak population is still lower than the 179.2/ mnn recorded for the area in 1999 (Yeboah, 2001) at a period when the population was expected to be picking up and not even at its peak. This decrease in bat abundance may, therefore, be due to the current high degree of disturbance and fragmentation taking place in the area due to 


\section{TABLE 1}

Bats species and numbers caught in the study area. (Figures in brackets are numbers per 100-m mist net night $(\mathrm{N} / \mathrm{mnn}))(a=$ figures from Survey $\mathrm{l}, b=$ figures from Survey II, $c=$ figures from Survey III)

\begin{tabular}{|c|c|c|c|c|c|c|c|c|c|}
\hline & & & & Sit & tes & & & & \\
\hline Species & $1^{* *}$ & $2^{* *}$ & $3^{* *}$ & 4 & 5 & $6^{*}$ & 7 & $8^{*}$ & Total \\
\hline Megachiroptera & & & & & & & & & \\
\hline Epomophorus & $16^{\mathrm{a}}$ & $12^{a}$ & $7^{\mathrm{a}}$ & $19^{a}$ & $6^{a}$ & $0^{a}$ & $0^{a}$ & $0^{a}$ & $60(83.3)$ \\
\hline gambianus & $19^{b}$ & $8^{b}$ & $7^{\mathrm{b}}$ & $20^{b}$ & $0^{\mathrm{b}}$ & $0^{\mathrm{b}}$ & $0^{\mathrm{b}}$ & $0^{\mathrm{b}}$ & $54(75)$ \\
\hline & $6^{c}$ & $0^{c}$ & $36^{c}$ & $6^{c}$ & $0^{c}$ & $22^{c}$ & $6^{c}$ & $0^{c}$ & $76(105.6)$ \\
\hline Epomops franqueti & $17^{\mathrm{a}}$ & $0^{a}$ & $0^{a}$ & $13^{a}$ & $17^{\mathrm{a}}$ & $6^{a}$ & $4^{a}$ & $5^{a}$ & $62(86.1)$ \\
\hline & 19 & $9^{b}$ & $0^{\mathrm{b}}$ & $12^{b}$ & $31^{\mathrm{b}}$ & $13^{b}$ & $0^{\mathrm{b}}$ & $9^{b}$ & $93(129.2)$ \\
\hline & $18^{c}$ & $0^{c}$ & $12^{c}$ & $11^{\mathrm{c}}$ & $12^{c}$ & $18^{\mathrm{c}}$ & $6^{c}$ & $12^{c}$ & $89(123.6)$ \\
\hline Scotonycteris zenkeri & $0^{a}$ & $5^{a}$ & $0^{a}$ & ${ }^{\mathrm{a}} 0$ & $0^{a}$ & $0^{a}$ & $0^{a}$ & $0^{a}$ & $5(6.9)$ \\
\hline & $0^{\mathrm{b}}$ & $0^{b}$ & $0^{\mathrm{b}}$ & $0^{\mathrm{b}}$ & $0^{\mathrm{b}}$ & $0^{b}$ & $12^{b}$ & $34^{b}$ & $46(63.9)$ \\
\hline & $6^{c}$ & $0^{c}$ & $0^{c}$ & $0^{c}$ & $0^{c}$ & $0^{c}$ & $0^{c}$ & $4^{c}$ & $10(13.7)$ \\
\hline Myonycteris leptodon & $0^{a}$ & $0^{a}$ & $0^{a}$ & $0^{a}$ & $0^{a}$ & $0^{a}$ & $6^{a}$ & $12^{\mathrm{a}}$ & $18(25.0)$ \\
\hline & $0^{\mathrm{b}}$ & $0^{b}$ & $0^{\mathrm{b}}$ & $0^{\mathrm{b}}$ & $0^{\mathrm{b}}$ & $0^{b}$ & $0^{\mathrm{b}}$ & $0^{\mathrm{b}}$ & 0 \\
\hline & $18^{c}$ & $6^{c}$ & $0^{c}$ & $0^{c}$ & $0^{c}$ & $6^{c}$ & $11^{\mathrm{c}}$ & $77^{c}$ & $118(163.9)$ \\
\hline Rousettus & $0^{a}$ & $6^{a}$ & $0^{a}$ & $0^{a}$ & $0^{a}$ & $0^{a}$ & $1^{\mathrm{a}}$ & $23^{a}$ & $30(41.7)$ \\
\hline aegyptiacus & $0^{\mathrm{b}}$ & $8^{b}$ & $0^{\mathrm{b}}$ & $0^{\mathrm{b}}$ & $0^{\mathrm{b}}$ & $0^{\mathrm{b}}$ & $0^{\mathrm{b}}$ & $0^{b}$ & $8(11.1)$ \\
\hline occidetalis & $0^{c}$ & $17^{\mathrm{c}}$ & $6^{c}$ & $0^{c}$ & $0^{c}$ & $12^{c}$ & $0^{c}$ & $6^{c}$ & $41(50.9)$ \\
\hline Nannonycteris & $0^{a}$ & $0^{a}$ & $0^{a}$ & $0^{a}$ & $0^{a}$ & $0^{a}$ & $0^{a}$ & $0^{a}$ & $0^{a}$ \\
\hline veldcampi & $0^{\mathrm{b}}$ & $0^{b}$ & $0^{\mathrm{b}}$ & $7^{b}$ & $0^{\mathrm{b}}$ & $0^{\mathrm{b}}$ & $0^{\mathrm{b}}$ & $0^{b}$ & $7(9.7)$ \\
\hline & $0^{c}$ & $17^{\circ}$ & $69^{\circ}$ & $0^{c}$ & $27^{c}$ & $22^{c}$ & $0^{c}$ & $0^{c}$ & $130(180.6)$ \\
\hline Megaloglossus & $0^{a}$ & $0^{a}$ & $0^{a}$ & $0^{a}$ & $0^{a}$ & $0^{a}$ & $0^{a}$ & $0^{a}$ & 0 \\
\hline woermanni & $0^{\mathrm{b}}$ & $0^{\mathrm{b}}$ & $0^{\mathrm{b}}$ & $0^{\mathrm{b}}$ & $0^{\mathrm{b}}$ & $0^{\mathrm{b}}$ & $0^{b}$ & $0^{\mathrm{b}}$ & 0 \\
\hline & $22^{c}$ & $0^{c}$ & $6^{c}$ & $0^{c}$ & $0^{c}$ & $0^{c}$ & $0^{c}$ & $0^{c}$ & $28(38.9)$ \\
\hline Lissonycteris & $0^{a}$ & $0^{a}$ & $0^{a}$ & $0^{a}$ & $0^{a}$ & $0^{a}$ & $0^{a}$ & $0^{a}$ & 0 \\
\hline angolensis & $0^{\mathrm{b}}$ & $0^{\mathrm{b}}$ & $0^{\mathrm{b}}$ & $0^{\mathrm{b}}$ & $0^{\mathrm{b}}$ & $0^{\mathrm{b}}$ & $0^{\mathrm{b}}$ & $0^{\mathrm{b}}$ & 0 \\
\hline & $10^{c}$ & $12^{c}$ & $12^{c}$ & $0^{c}$ & $0^{c}$ & $0^{c}$ & $0^{c}$ & $0^{c}$ & $34(47.2)$ \\
\hline Hypsiygnathusmonst & $0^{a}$ & $0^{a}$ & $0^{a}$ & $0^{a}$ & $0^{a}$ & $0^{a}$ & $0^{a}$ & $0^{a}$ & 0 \\
\hline rosus & $0^{\mathrm{b}}$ & $0^{\mathrm{b}}$ & $0^{\mathrm{b}}$ & $0^{\mathrm{b}}$ & $0^{\mathrm{b}}$ & $0^{\mathrm{b}}$ & $0^{b}$ & $0^{\mathrm{b}}$ & 0 \\
\hline & $0^{c}$ & $0^{\circ}$ & $0^{c}$ & $0^{c}$ & $0^{c}$ & $4^{c}$ & $0^{c}$ & $0^{c}$ & $4(5.6)$ \\
\hline Micropteropus pusillus & $0^{a}$ & $0^{a}$ & $6^{a}$ & $0^{a}$ & $0^{a}$ & $0^{a}$ & $0^{a}$ & $0^{a}$ & $6(8.3)$ \\
\hline & $0^{\mathrm{b}}$ & $0^{b}$ & $6^{b}$ & $0^{\mathrm{b}}$ & $0^{\mathrm{b}}$ & $18^{b}$ & $0^{\mathrm{b}}$ & $0^{\mathrm{b}}$ & $24(33.3)$ \\
\hline & $0^{c}$ & $6^{c}$ & $12^{c}$ & $6^{c}$ & $17^{c}$ & $0^{c}$ & $0^{c}$ & $60^{c}$ & $47(65.3)$ \\
\hline Total & $33(45.8)$ & $23(31.9)$ & $7(9.7)$ & $38(52.8)$ & 23(31.9) & $6(8.3)$ & $11(15.3)$ & $40(56)$ & $181(251.4$ \\
\hline b & $38(52.7)$ & $25(34.7)$ & $13(18.1)$ & $39(54.2)$ & $31(43.1)$ & $31(43.1)$ & $12(16.7)$ & $43(59.7)$ & 232(322.2) \\
\hline c & $80(112.5)$ & $58(80.6)$ & $153(212.5)$ & $23(31.9)$ & $51(70.8)$ & $84(116.7)$ & $23(31.9)$ & $105(145.8)$ & $577(801.4$ \\
\hline
\end{tabular}

* Sites in the Mamang Forest Reserve

** Sites in the Ajenjua Forest Reserve 
TABLE 2

Number of megachiropteran bats caught and percentages of females pregnant or lactating in the study area ( $a$ = figures for Survey $I, b=$ figures for Survey II, $c=$ figures from Survey III)

\begin{tabular}{|c|c|c|c|c|c|c|c|c|c|c|c|c|c|c|c|}
\hline \multirow[t]{2}{*}{ Species } & \multicolumn{3}{|c|}{$\begin{array}{l}\text { Total no. } \\
\text { caught }\end{array}$} & \multicolumn{3}{|c|}{$\begin{array}{l}\text { No. of } \\
\text { males }\end{array}$} & \multicolumn{3}{|c|}{$\begin{array}{l}\text { No. of } \\
\text { females }\end{array}$} & \multicolumn{3}{|c|}{$\begin{array}{l}\text { No. preg. or } \\
\text { lactating }\end{array}$} & \multicolumn{3}{|c|}{$\begin{array}{c}\text { Percent } \\
\text { pregnant or } \\
\text { lactating }\end{array}$} \\
\hline & $a$ & $b$ & $c$ & $a$ & $b$ & $c$ & a & $b$ & $c$ & a & $b$ & $c$ & a & $b$ & $c$ \\
\hline Epomophorus gambianus & 60 & 54 & 76 & 33 & 24 & 42 & 27 & 30 & 34 & 22 & 0 & 15 & 81 & 0 & 44.1 \\
\hline Epomops franqueti & 62 & 93 & 89 & 34 & 33 & 69 & 26 & 60 & 20 & 26 & 0 & 2 & 100 & 0 & 10.0 \\
\hline Scotonycteris zenkeri & 5 & 46 & 10 & 5 & 27 & 10 & 0 & 20 & 0 & 0 & 7 & 0 & 0 & 35 & - \\
\hline Myonycteris leptodon & 18 & 0 & 118 & 7 & 0 & 83 & 11 & 0 & 35 & 8 & 0 & 17 & 73 & 0 & 48.6 \\
\hline $\begin{array}{l}\text { Rousettus aegytiacus } \\
\text { occidentalis }\end{array}$ & 30 & 8 & 41 & 13 & 3 & 23 & 17 & 5 & 18 & 6 & 0 & 2 & 35 & 0 & 11.1 \\
\hline Micropteropus pusillus & 6 & 24 & 47 & 6 & 17 & 17 & 0 & 13 & 30 & 0 & 13 & 9 & 0 & 100 & 30.0 \\
\hline Nannonycteris veldkampi & 0 & 71 & 30 & 0 & 4 & 120 & 0 & 3 & 10 & 0 & 0 & 0 & 0 & 0 & 0.0 \\
\hline $\begin{array}{l}\text { Lissonycteris angolensis } \\
\text { angolensis }\end{array}$ & 0 & 0 & 34 & 0 & 0 & 16 & 0 & 0 & 18 & 0 & 0 & 6 & 0 & 0 & 33.3 \\
\hline $\begin{array}{l}\text { Megaloglossus } \\
\text { woermanni }\end{array}$ & 0 & 0 & 28 & 0 & 0 & 26 & 0 & 0 & 2 & 0 & 0 & 0 & 0 & 0 & 0.0 \\
\hline Hypsignathus monstrosus & 0 & 0 & 4 & 0 & 0 & 4 & 0 & 0 & 0 & 0 & 0 & 0 & 0 & 0 & 0.0 \\
\hline
\end{tabular}

mining exploration and illegal logging.

During the first survey (Survey I), all the species of bats of which females were caught showed various degrees of breeding condition in terms of pregnancy or lactation (Table 2). For example, all females of E. franqueti and $81 \%$ of Epomophorus gambianus that were caught were pregnant or lactating. Most of these gravid females were in their late pregnancies and a few of them were lactating with their young firmly attached to the mother's breast nipple. In Survey II, none of these species was pregnant. Instead there were many young individuals in the sample resulting in an increase in relative abundance. Also two species (M. pusillis and S. zenkeri) that were not pregnant in the first survey were pregnant, suggesting that for some reasons these smaller sized bats have a different breeding season. In Survey III, pregnancies were recorded in some bat species. These were E. gambianus (44.1\%), M. leptodon (48.6\%), R. aegytiacus (11.1\%), $M$. pussilus (30\%) and L. angolensis (33.3\%).

It appears that for E. gambianus, E. franqueti, $M$. leptodon and $R$. aegyptiacus there are two breeding seasons: the major one in July /August and a minor one in March/ April. M. pussilus also has two breeding seasons but the major one is in November/December and the minor in March/ April. Pregnant $S$. zenkeri females were caught only in Survey II (November/December) and 35 per cent pregnancy was recorded. In a similar survey carried out by the author for Goldfields Ghana Ltd in the Western Region during the third week of April 2004, 33 per cent pregnancy $(n=9)$ 
was recorded. It, therefore, appears that like $M$. pussilus, $S$. zenkeri has two breeding seasons (November/December and April). The information so far gathered, thus, indicates that Ghanaian megachiropteran bats are capable of producing two litters in a year. For Lissonycteris angolensis, no captures were made in Surveys I and II but those caught in Survey III indicate breeding season in March/April.

\section{Conclusion}

The indications are that very little studies have been carried out on fruit bats in Ghana, especially with respect to population dynamics and reproduction. Findings from the present study indicate that there are seasonal variations in fruit bat numbers and reproduction. The bats have also been found to be capable of producing two litters in a year. These findings were made in the Eastern Region of Ghana. The question then is " are these findings true for every part of the country where the species are found, or are there regional differences due to differences in vegetation types?". In order to answer this question there is the need for similar studies to be carried out in other areas of the country, especially in the moist evergreen forests of the Western Region. There is also the need for some work to be initiated on micricheropteran (insectivorous) bats on which published information is virtually non-existent. It is hoped that mammalogists in Ghana will take up this challenge.

\section{Acknowledgement}

Funds for the study were provided by Newmont Ghana Ltd Gold Mines and S. G. S. (Environment).

\section{References}

Ayensu, E. S (1974) Plant and bat interaction in West Africa. Ann. Mo. Bot. Gadn 61 702-727.

BAKER, H. G. \& HARRIS, B. J. (1957) The pollination of Parkia by bats and its attendant evolutionary problems. Evolution 11, 449-460.

BAKER, H. G. \& HARRIS, B. J. (1959) Bat pollination of the silk cotton tree, Ceiba pentandra (L.) Gaertn. (Sensu lato) in Ghana. J. West Afri. Sci. Assc. 5, 1-9.

Воотн, A. H. (1956) Some Gold Coast mammals not included in Cansdale's Provisional Checklist. J. West Afr. Sci. Ass. 2, 137-138.

Воотн, A. H. (1959) On the mammalian fauna of the Accra Plain. J. West Afr. Sci. Ass. 5, 26-36.

Decher, J. (1996) Small mammal communities and their conservation on the Accra Plains of Ghana. (Unpublished Doctoral Dissertation.) University of Minnesota. $148 \mathrm{pp}$.

JEFFERY, S. (1974) Notes on mammals from the high forest of Western Ghana. I.F.A.H., Ser. A. 37, 950973.

Lack, A. (1978) The ecology of the flower of the savanna tree Maranthes polyandra and their visitors, with particular reference to bats. J. Ecol. 66, 287295.

Marshall, A. G. \& McWilliams, A. N. (1962) Ecological observations on epomorphorine fruit bats (Megachiroptera) in West African Savanna woodland. J. Zool. Lond. 198, 53-57.

Rosevear, D. R. (1965) The Bats of West Africa. British History Museum (Natural History), London.

Yеводн, S. (1996). Small mammals and the herpetofauna of the Kakum National Park. Facing the storm (Proceedings of the Kakum Consevation Area Research Colloquim). Consv. Int. Washington D. C. pp. $37-45$.

Yеводн, S. (1998) Small mammal diversity in the Kakum National Park. Ghana J. Sci. 38, 25-32.

YeBoAh, S. (2001) The distribution and relative abundance of Megachiropteran bats in Southern Ghana. J. Ghana Sci. Ass. 3(1), 99-105 